\title{
Rare Birds in Ecuador: Third Report of the Committee for Ecuadorian Records in Ornithology (CERO)
}

\author{
Juan F. Freile ${ }^{1,2 *}$, Alejandro Solano-Ugalde ${ }^{1,3}$, Dušan M. Brinkhuizen ${ }^{1,4}$, Paul J. Greenfield ${ }^{1,5}$, Mitch Lysinger ${ }^{1,6}$, Jonas Nilsson ${ }^{1,7}$, Lelis Navarrete ${ }^{1}$, Robert S. Ridgely ${ }^{1,8}$ \\ ${ }^{1}$ Comité Ecuatoriano de Registros Ornitológicos (CERO). \\ ${ }^{2}$ Red Aves Ecuador. Pasaje El Moro E4-216 y Norberto Salazar, Tumbaco. \\ ${ }^{3}$ Fundación Imaymana, Paltapamba 476, San Pedro del Valle, Nayón. \\ ${ }^{4}$ Rockjumper Birding Tours, Casilla Postal 17-07-9345, Quito. \\ ${ }^{5}$ Mindo Cloudforest Foundation, Urb. El Bosque, 2da Etapa, calle Sexta \#161, edif. El Parque, Quito. \\ ${ }^{6}$ Cabañas San Isidro, avenida Siena 318 y calle A, edif. MDX, of. 310, Cumbayá. \\ ${ }^{7}$ Wildsumaco Lodge, Leonardo da Vinci 239 y Rafael Sanzio, edif. Oberer, Cumbayá. \\ ${ }^{8}$ ARainforest Trust, 7078 Airlie Road, Warrenton, VA 20187. \\ *Autor para correspondencia/Corresponding author,e-mail: cero.ecuador@gmail.com \\ Editado por/Edited by: \\ Recibido/Received: . Aceptado/Accepted: . \\ Publicado en línea/Published on Web: . Impreso/Printed: .
}

DOI:

Aves raras en Ecuador: tercer reporte del Comité Ecuatoriano de Registros Ornitológicos (CERO)

\section{Resumen}

Presentamos nuevos registros de distribución de aves del Ecuador que han sido presentados al Comité Ecuatoriano de Registros Ornitológicos (CERO) entre abril 2014 y agosto 2015. Incluimos reportes de seis especies nuevas para Ecuador (Anas crecca, Thalassarche bulleri, Puffinus puffinus, Morus sp., Numenius americanus y Elaenia strepera), una especie nueva para el Ecuador continental (Fregetta grallaria), cuatro especies con primera documentación en Ecuador (Calidris alpina, Larus argentatus, Stercorarius longicaudus y Tyrannus dominicensis), extensiones considerables de distribución de 14 especies (Podilymbus podiceps, Pterodroma phaeopygia, Charadrius semipalmatus, C. collaris, Bartramia longicauda, Calidris alba, Limnodromus scolopaceus, Phalaropus fulicarius, Stercorarius longicaudus, Sternula superciliaris, Chlidonias niger, Galbula dea, Elaenia spectabilis y Geothlypis philadelphia), nuevos reportes de 12 especies raras (Aythya affinis, Sula leucogaster, Busarellus nigricollis, Stercorarius chilensis, Chordeiles minor, Psittacara wagleri, Philydor fuscipenne, Muscisaxicola fluviatilis, Pyroderus scutatus, Passerina caerulea, Vermivora chrysoptera y Setophaga castanea) y el primer reporte moderno de Oreopholus ruficollis. Presentamos el primer registro en Ecuador de la subespecie Lurocalis semitorquatus semitorquatus y el segundo registro de la subespecie Petrochelidon pyrrhonota melanogaster. Finalmente, invalidamos los registros previos de Picumnus castelnau, especie que no habita en Ecuador. CERO revisa y actualiza el listado de aves del Ecuador, que en la actualidad alcanza las 1679 especies (1626 confirmadas y documentadas, y 53 no documentadas).

Palabras Clave. Aves, nuevos registros, extensiones de distribución.

\begin{abstract}
Here we present noteworthy records of birds in Ecuador submitted to the Committee for Ecuadorian Records in Ornithology (CERO) from April 2014 through August 2015. This report includes six species new to Ecuador (Anas crecca, Thalassarche bulleri, Puffinus puffinus, Morus sp., Numenius americanus and Elaenia strepera), one species new to continental Ecuador (Fregetta grallaria), four species with first documented records (Calidris alpina, Larus argentatus, Stercorarius
\end{abstract}


longicaudus and Tyrannus dominicensis), remarkable range extensions for 14 species (Podilymbus podiceps, Pterodroma phaeopygia, Charadrius semipalmatus, C. collaris, Bartramia longicauda, Calidris alba, Limnodromus scolopaceus, Phalaropus fulicarius, Stercorarius longicaudus, Sternula superciliaris, Chlidonias niger, Galbula dea, Elaenia spectabilis and Geothlypis philadelphia), and new records of 12 rare species (Aythya affinis, Sula leucogaster, Busarellus nigricollis, Stercorarius chilensis, Chordeiles minor, Psittacara wagleri, Philydor fuscipenne, Muscisaxicola fluviatilis, Pyroderus scutatus, Passerina caerulea, Vermivora chrysoptera and Setophaga castanea), and the first modern record of Oreopholus ruficollis. We present the first record of the subspecies Lurocalis semitorquatus semitorquatus, and the second record of the subspecies Petrochelidon pyrrhonota melanogaster. Finally, we invalidate previous records of Picumnus castelnau, a species that does not occur in Ecuador. CERO revises and updates the bird list of Ecuador, which currently stands at 1679 species (1626 confirmed and documented; 53 undocumented).

Keywords. Birds, new country records, range extensions.

\section{INTRODUCTION}

With two annual reports published to date, the Committee for Ecuadorian Records in Ornithology (CERO) has updated and revised the national checklist of birds with data reported by several observers from February 1997 through March 2014 (Freile et al., 2013; Nilsson et al., 2014). To date, CERO has reported 15 new country records (13 species and 2 subspecies), first documented records for 19 species, and significant range extensions for over 60 species. Likewise, CERO has removed six species from the country's bird list due to previous identification or collections errors (Janni \& Pulcher, 2007; Nilsson et al., 2014).

The increasing number of observers compiling and publishing information on the birds of Ecuador, combined with an ongoing upsurge in ornithological literature on the systematics of Neotropical birds (Remsen et al., 2016), has generated numerous advances in the knowledge of the taxonomy, distribution, ecology, and status of Ecuadorian birds. The goal of CERO is to contribute to this growing body of information by periodically updating, revising and publishing the official checklist of birds of Ecuador on its webpage: www.ceroecuador.wordpress.com

Currently, the Ecuador bird list, including the results presented in this third report, stands at 1679 species (53 undocumented) (Freile et al., 2016).

\section{METHODS}

CERO receives and reviews record forms of rare species, new country records, and/or significant range extensions, voluntarily submitted by the observer or observers themselves through CERO's webpage and e-mail address (cero. ecuador@gmail.com). The updated country checklist and a list of 'most-wanted' species are published in the webpage, allowing observers to consult the status of the birds of Ecuador. New country records are evaluated and have to be accepted by unanimous vote, while first documentation and undocumented records of previous hypothetical species are accepted by majority vote.

Most sound-recordings were deposited by observers at xeno-canto online archive (www.xeno-canto.org), for which a XC code and citation are provided in the species accounts. Photographs are deposited at CERO digital archives, and most are published in this report (Figs. 1-8). Locality coordinates and elevation are provided in Table 1 . New country records are marked with an asterisk $\left(^{*}\right)$ in the species accounts. Taxonomy and species sequence follows the latest (August 2016) version of SACC (Remsen et al., 2016).

In this report CERO presents 51 records of 45 species submitted in the period from April 2014 through August 2015. The received records were made between September 1996 and June 2015, using different survey protocols and documentation techniques. 


\section{RESULTS AND DISCUSSION}

\section{Green-winged Teal Anas crecca}

Record no. 2015-031: Province of Manabí, La Segua, 28 and 30 December 2014, R. Ahlman, D. Brinkhuizen and J. Nilsson (photo).

A single drake was first observed on 28 December 2014 by R. Ahlman. It was foraging among a flock of Blue-winged Teal Anas discors and White-cheeked Pintail A. bahamensis. It was relocated by D. Brinkhuizen and J. Nilsson on 30 December 2014, at the same place. This record was first published, including voucher photograph, by Ahlman (2016). The species regularly winters in southern North America, Central America and the Caribbean, with few accidental records in northern Colombia, northern Venezuela, and Trinidad and Tobago (Madge \& Burn, 1988; Restall et al., 2006).

\section{Lesser Scaup Aythya affinis}

Record no. 2015-029: Province of Cotopaxi, Laguna de Yambo, January-March 2014, A. Soria, S. Niquinga, J. M. Loaiza, J. Bedoya, J. Freile, A. Naveda, and G. Bucheli (photo).

Two females were observed from late January through late March during waterbird censuses and birding visits (Fig. 5a). They were feeding among a flock of Ruddy Ducks Oxyura jamaicensis in fairly shallow waters along the lake's shoreline. Record localities and overall numbers of this boreal migrant duck in Ecuador have notably increased in recent years (Freile et al., 2013; Nilsson et al., 2014), suggesting that the species is currently an annual visitor to northern Ecuador. This is the species' southernmost record in the Interandean valley of Ecuador, and the first for Laguna de Yambo.

\section{Pied-billed Grebe Podilymbus podiceps}

Record no. 2014-050: Province of Napo, Laguna Añangucocha, 2 February 2014, C. Talkington (photo).

A single individual was seen at close range (less than $100 \mathrm{~m}$ ) swimming at Laguna Añangucocha, Napo Wildlife Centre (Fig. 4a). This represents the species' first record for eastern Ecuador, 190-200 km E of its breeding range in the Andean wetlands in Pichincha and Imbabura provinces (Ridgely \& Greenfield, 2001). This individual most likely belongs to the subspecies $P$. p. antarcticus, because of its proportionately heavy and thick bill.

\section{*Buller's Albatross Thalassarche bulleri}

Record no. 2014-041: Province of Santa Elena, Ayangue, 1997, R. Carvajal and P. Amador (fide B. Haase) (photo).

One fresh, washed-out dead individual was found and photographed on an undetermined date (possibly April) in 1997 at Ayangue (Haase, 2011). The specimen was not collected but a single photograph was delivered to B. Haase (Fig. 1a). Bill and underwing patterns confirm the identification, excluding similar Grey-headed Thalassarche chrysostoma and Salvin's T. salvini albatrosses (Onley \& Scofield, 2007). This represents the first record for Ecuador (Ridgely \& Greenfield, 2001; Freile et al., 2016). The species has been reported as a rare austral visitor to south and central Peru (Schulenberg et al., 2007), but regularly winters off central Chile (Onley \& Scofield, 2007).

\section{Galapagos Petrel Pterodroma phaeopygia}

Record no. 2014-042: Province of Carchi, Gualchán, 16 March 2010, José María Loaiza, and José Hernández (photo).

A single adult male, as labeled by the collectors, was found by José Hernández. The bird was present along a small river for c. 3 months before it weakened, and was finally trapped for inspection, but died (Fig. 4b). The specimen is deposited at the Museo Ecuatoriano de Ciencias Naturales (MECN 0192). This represents the first record for inland Ecuador, c. $105 \mathrm{~km}$ from the coast at an elevation of c. $1100 \mathrm{~m}$ (Ridgely \& Greenfield, 2001; Freile et al., 2016), and the first inland continental record we are aware of a Pterodroma petrel (Onley \& Scofield, 2007). 
Table 1: Localities of records submitted to the Committee for Ecuadorian Records in Ornithology (CERO) between April 2014 and August 2015. Asterisk indicates localities mentioned in species accounts only, not records submitted to CERO.

\begin{tabular}{|c|c|c|}
\hline Locality, province & Coordinates & Elevation (m) \\
\hline $15 \mathrm{~km}$ on Pachijal-Guayabillas road, Pichincha & c. $0.203 /-78.897$ & c. 700 \\
\hline 2 Km N San Cristóbal, Galápagos & $-0.65 /-89.366$ & 0 \\
\hline 3-4 km S Catamayo, Loja & $-4.05 /-79.367$ & 1200 \\
\hline $7 \mathrm{~km} \mathrm{~N}$ of Canelos, Pastaza & $-1.525 /-77.761$ & 700 \\
\hline Aeropuerto de Quito, Tababela, Pichincha & $-0.108 /-78.365$ & 2350 \\
\hline Atacames bypass, Esmeraldas & $0.866 /-79.833$ & 50 \\
\hline Ayangue, Santa Elena & $-1.983 /-80.733$ & 0 \\
\hline Bermejo, Sucumbíos* & $0.176 /-77.360$ & 980 \\
\hline Camino de Borja, Napo & $0.416 /-77.833$ & c. 1600 \\
\hline Canal Bolívar, Galápagos & $-0.2069 /-91.4616$ & 0 \\
\hline Cascada de San Rafael, Napo* & $-0.109 /-77.593$ & 1250 \\
\hline Durán, Guayas* & $-2.20 /-79.833$ & 3 \\
\hline El Corazón de Nuevo Mundo, Carchi & $0.70 /-78.133$ & 1595 \\
\hline Gualchán, Carchi & $0.711 /-78.197$ & c. 1100 \\
\hline Isla de los Pájaros, Esmeraldas* & $1.366 /-78.9$ & 0 \\
\hline Isla Española, Galápagos* & $1.416 /-89.70$ & 0 \\
\hline Jardín Botánico de Quito, Pichincha & $-0.186 /-78.485$ & 2780 \\
\hline Kapawi, Pastaza* & $-2.75 /-76.75$ & 200 \\
\hline La Chocolatera, Santa Elena & $-2.189 /-81.011$ & 0 \\
\hline La Segua, Manabí & $-0.713 /-80.201$ & 2 \\
\hline La Selva, Sucumbíos & $-0.498 /-76.373$ & 250 \\
\hline Lagartococha, Sucumbíos* & $-0.601 /-75.244$ & 180 \\
\hline Laguna Añangucocha, Orellana & $-0.533 /-76.400$ & 220 \\
\hline Laguna de Papallacta, Napo & $-0.376 /-78.166$ & 3356 \\
\hline Laguna de Yambo, Cotopaxi & $-1.102 /-78.589$ & 2585 \\
\hline Laguna Limpiopungo, Cotopaxi* & $-0.62 /-78.476$ & 3660 \\
\hline Las Peñas, Esmeraldas & $1.10 /-79.15$ & 0 \\
\hline Limoncocha, Sucumbíos & $-0.390 /-76.599$ & 230 \\
\hline Mindo, Pichincha* & $-0.083 /-78.767$ & 1260 \\
\hline Near Guadual, Imbabura & c. $0.688 /-78.197$ & 1800 \\
\hline off Salinas, Santa Elena & c. $-2.20 /-81.216$ & 0 \\
\hline Playa de Tarqui, Manabí & $-0.933 /-80.716$ & 0 \\
\hline Playas de Chito, Zamora Chinchipe & $-4.9419 /-79.053$ & 1040 \\
\hline Puente de Chimbo, Chimborazo* & $-2.213 /-79.136$ & 330 \\
\hline Puerto Pitahaya, El Oro* & $-3.424 /-80.077$ & 0 \\
\hline Punta Carnero, Santa Elena & $-2.289 /-80.913$ & 1 \\
\hline Reservorio de Cumbayá, Pichincha & $-0.193 /-78.427$ & 2360 \\
\hline Río Bigal Biological Reserve, Orellana & $-0.537 /-77.425$ & 900 \\
\hline Río Blanco, Esmeraldas* & $0.0435 /-79.403$ & 90 \\
\hline Río Napo near Añangu, Orellana & c. $-0.505 /-76.401$ & c. 220 \\
\hline Río Verde, Sucumbíos* & $0.237 /-77.576$ & 750 \\
\hline Samana, Los Ríos & $-1.657 /-79.323$ & 700 \\
\hline San Sebastián, Galápagos & Unknown locality & 0 \\
\hline Tipischa, Sucumbíos & $0.295 /-76.177$ & c. 300 \\
\hline Tiputini Biodiversity Station, Orellana & $-0.638 /-76.150$ & c. 235 \\
\hline Sarayacu, Loreto, Peru & $-6.733 /-75.10$ & 125 \\
\hline Yaguarcocha, Imbabura* & $0.372 /-78.103$ & 2200 \\
\hline
\end{tabular}

\section{*Manx Shearwater Puffinus puffinus}

Record no. 2015-030: Province of Galápagos, 2 km N of San Cristóbal Island, 13 August 2011, G. Armistead (photo). An adult was recorded by G. Armistead $2 \mathrm{~km} \mathrm{~N}$ of San Cristóbal, and a single photograph was published in Cotinga 

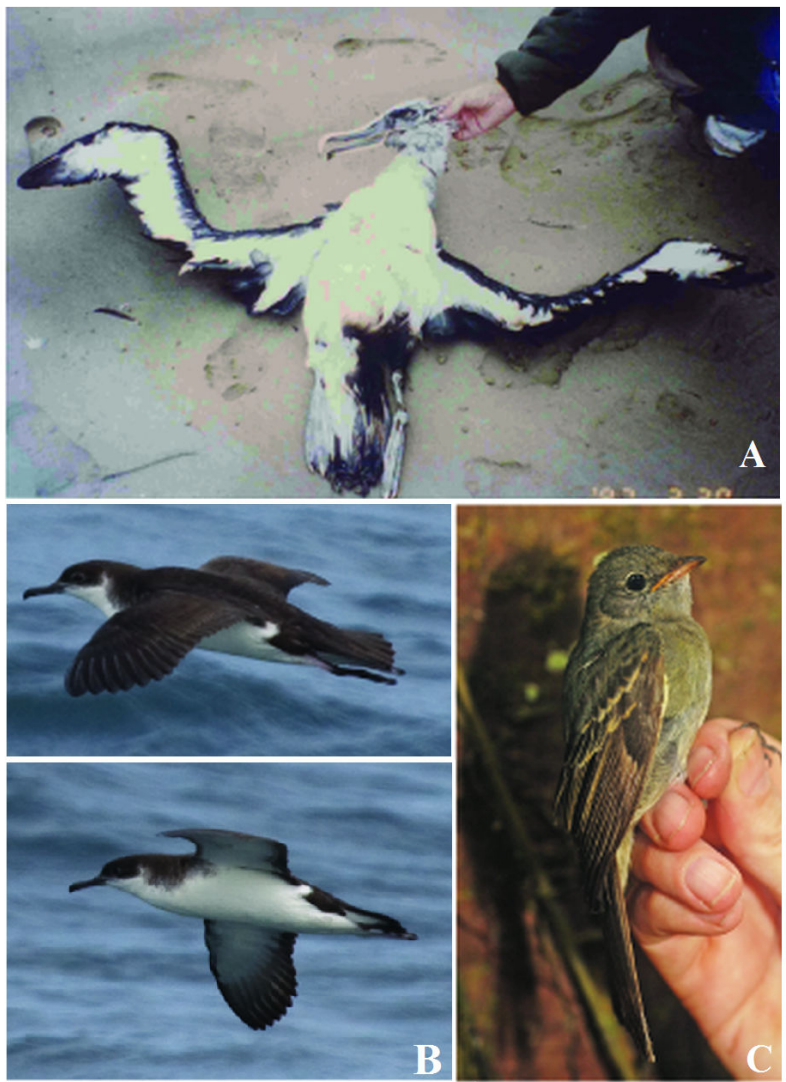

Figure 1: New country records for Ecuador. a) Thalassarche bulleri (R. Carvajal, P. Amador); b) Puffinus puffinus (G. Armistead); c) Elaenia strepera (J. G. Blake).

34: 186 (Kirwan et al., 2012). Additional photos submitted by the observer to CERO allowed for a more thorough assessment to confirm its identification (Fig. 1b). This is the first record for Galápagos and Ecuador (Wiedenfeld, 2006; Freile et al., 2016). This Atlantic Ocean species has occasionally been reported from the Pacific Ocean off Washington, Oregon and California, USA, south to Oaxaca, Mexico; also around Cape Horn and off S and C Chile (Sibley, 2003; Howell, 2012; Carboneras et al., 2016).

\section{${ }^{*}$ White-bellied Storm-Petrel Fregetta grallaria}

Record no. 2015-004: Province of Santa Elena, La Chocolatera, 25 August 2014, J. Nilsson.

A presumably adult bird was observed flying slowly, alternating between glides and flaps, and tilting from side to side, periodically (every $4-5 \mathrm{~m}$ ) dashing its breast against the water, then bouncing free while dangling its feet. Several times it sliced the water's surface with one wing tip, a behavior described as typical and distinctive of the genus Fregetta (Onley \& Scofield, 2007). It was observed at 80-100 m distance range under good to medium light conditions. Careful study of field characters permitted identification from congeners and from the less chunky Oceanodroma and Oceanites storm-petrels. There are a few confirmed records from Galápagos, including one specimen (Wiedenfeld, 2006), but no previous records of this species from Ecuador's mainland coast. It normally ranges well to the west of mainland Ecuadorian waters (Onley \& Scofield, 2007), with a few undocumented records from Peru (Schulenberg et al., 2007), but post-breeding movements are not well known (Onley \& Scofield, 2007). Given the lack of documentation to support this record, the species is classified as hypothetical (i.e., undocumented) for mainland Ecuador.

\section{Brown Booby Sula leucogaster}

Record no. 2015-006: Province of Santa Elena, La Chocolatera, 6 September 2014, C. Hinkle, A. Hinkle, J. Nilsson and B. Haase (photo).

A single individual was observed flying southwards, low over the water. The species has been regularly observed 
at La Chocolatera since 2013 (Freile et al., 2013; Nilsson et al., 2014), with earlier records from 2010 (Haase, 2011). Despite the low number of records until 2010, we now believe S. leucogaster is a regular wanderer or transient along the Ecuadorian coast. Therefore, CERO no longer requests records of this species from the Santa Elena province.

\section{* Gannet sp. Morus sp.}

Record no. 2015-023: Province of Santa Elena, La Chocolatera, 13 May 2002, B. Haase.

An adult was observed flying low over the water, at a distance of c. $150 \mathrm{~m}$. The bird was alone, flying northwest. The following characters were noted: very large 'booby', white body and basal half of wings; pale lead-grey bill with dark linings; black mask; noticeable yellow cast to crown and hindneck; black flight feathers and tail. The bird was identified as Cape Gannet Morus capensis by the observer, who provided a detailed description, with comparisons of Sula species known to visit the Ecuadorian coast, either regularly or accidentally. However, description details were insufficient to separate it from the extremely similar Australasian Gannet M. serrator (Harrison, 1987). Even though M. capensis - and not M. serrator - has previously been recorded from the Pacific coast of South America (GarcíaGodos, 2002), we prefer to tentatively accept this record as a gannet Morus sp. Due to absence of documentation, the species is classified as hypothetical.

\section{Black-collared Hawk Busarellus nigricollis}

Record no. 2014-050: Province of Sucumbíos, Laguna Limoncocha, 29 May 2014, R. Ahlman (photo).

An adult was observed at the northeast section of Laguna Limoncocha, along a marsh-fringed, stream-like portion of the lake (Fig. 5b). In Ecuador, the species is known mainly from the Lagartococha River drainage at the far eastern border with Peru (Ridgely \& Greenfield, 2001), 130-150 km E of Limoncocha. It was not previously reported from Limoncocha despite extensive fieldwork from 1963 through 1976 (Pearson et al., 1972; Tallman \& Tallman, 1977).

\section{Tawny-throated Dotterel Oreopholus ruficollis}

Record no. 2015-021: Province of Santa Elena, La Chocolatera, 3-21 June 2015, B. Haase and J. Nilsson (photo).

A single adult was first found on 3 June and last seen on 21 June 2015 in open, barren, desert-like terrain bordering the ocean, with gently rolling sand dunes and rocky areas (Fig. 3). The previous mainland record for Ecuador was in 1898, when two birds were collected in Santa Elena Peninsula, one of them labeled as immature (Salvadori \& Festa, 1900). There is in addition a single observation of a bird photographed on Isla Española, Galápagos, on 23 June 1991 (Ridgely \& Greenfield, 2001). The bird of La Chocolatera belongs to the subspecies Oreopholus ruficollis pallidus as it showed pale buffy scapulars and wing-coverts with very thin black central stripes (nominate $O$. $r$. ruficollis has much broader, darker lines over a richer, deeper creamy background). It also had a paler grey crown, back and breast compared with the nominate form (Schulenberg et al., 2007). The subspecific identity of Ecuadorian birds has not been fully resolved, but Ridgely \& Greenfield (2001) suggested they were $O$. $r$. pallidus. Subspecific identity of the two 1898 specimens, as well as of the Galápagos bird has to be determined. The species was ranked as extirpated from Ecuador (Granizo, 2002) but it is not fully clear if $O$. ruficollis is a resident or an occasional wanderer from coastal Peru.

\section{Semipalmated Plover Charadrius semipalmatus}

Record no. 2015-016: Province of Pichincha, Aeropuerto de Quito, Tababela, 19 December 2014, J. Nilsson (photo).

A single bird was feeding on mudflats at a reservoir shore, at a distance of c. $200 \mathrm{~m}$. Due to the distance and given that no voice was heard, the Common Ringed Plover Charadrius hiaticula from Eurasia could not be entirely ruled out. However, we consider it very unlikely this species was involved, as there are no confirmed records in South America (Remsen et al., 2016). There are a few previous records of $C$. semipalmatus from Andean Ecuador (Ridgely \& Greenfield, 2001), including Reservorio de Cumbayá and Laguna Limpiopungo, 8 km W and 32 km SW of Tababela, respectively. 


\section{Collared Plover Charadrius collaris}

Record no. 2015-007: Province of Pichincha, Reservorio de Cumbayá, 30 October 2014, J. Nilsson (photo).

A single bird was observed from 30 October to 1 November 2014 (Fig. 4c). This is the species' first highland record in Ecuador, where it is normally found along riverbanks and beaches in the lowlands and along the coast (Ridgely \& Greenfield, 2001). There are few records in the Andes of Bolivia (Fjeldså \& Krabbe, 1990).

\section{Upland Sandpiper Bartramia longicauda}

Record no. 2015-017: Province of Manabí, Playa de Tarqui, Manta, 18 September 2014, J. Nilsson, B. Olson and J. Olson (photo).

A single individual was observed on a stone pier between the open ocean and a shallow bay with mudflats (Fig. 4d). There are only a few scattered records of this boreal migrant from the western lowlands, including an old specimen from Río Blanco, Esmeraldas province (Ridgely \& Greenfield, 2001), one bird observed at Salinas (Haase, 2011), and another one seen at Durán, Guayas province (R. Ahlman, in litt. 2011).

\section{${ }^{*}$ Long-billed Curlew Numenius americanus}

Record no. 2015-002: Province of Santa Elena, Punta Carnero, 29 August 1997, W. Nezadal.

An adult was observed for c. 5 min resting and preening on sandy mudflats behind a beach. The bird was described as being brown with a scaly upperside, more plain buffy underparts, lacking bold head-stripes of Whimbrel Numenius phaeopus, and being more cinnamon brown than N. phaeopus. It also appeared nearly the size of a nearby Snowy Egret Egretta thula, and was much bigger than Willet Tringa semipalmata, which was also feeding nearby. Bill was reported as extremely long and down-curved. Numenius americanus is known to winter primarily in Central America and the Caribbean, with few records from northernmost South America along the Caribbean coasts of Colombia, Venezuela, and Trinidad and Tobago (Hayman et al., 1986). The species has been accepted unanimously as hypothetical for Ecuador given the lack of documentation. The species is generally rare in South America and currently near-threatened (BirdLife International, 2016).

\section{Sanderling Calidris alba}

Record no. 2014-063: Province of Pichincha, Aeropuerto de Quito, Tababela, 10 November 2014, R. Ahlman (photo).

Record no. 2015-014: Province of Napo, Laguna de Papallacta, 18 November 2014, J. Nilsson (photo).

A single individual was observed and photographed on the rocky edge of the airport reservoir. Another bird in nonbreeding plumage was observed feeding at the shores of Laguna de Papallacta. There is one previous Andean record of this primarily coastal migrant in Ecuador from Yaguarcocha, Imbabura province (Santander et al., 2011 ), $50 \mathrm{~km}$ NNE of Tababela and $62 \mathrm{~km} \mathrm{~N}$ of Papallacta.

\section{Dunlin Calidris alpina}

Record no. 2014-062: Province of Esmeraldas, Las Peñas, 23 November 2014, R. Ahlman (photo, video).

A single immature was observed on a sandbar of an abandoned shrimp pond, resting among a group of c. 200 waders (Fig. 2a). Overall size and shape, bill length and shape, and the presence of rufous scapular fringing confirm its identification. There are three previous observations reported in the literature, from Santa Elena peninsula and the Isla de los Pájaros, near San Lorenzo, Esmeraldas province (Ridgely \& Greenfield, 2001; Haase, 2011; Freile et al., 2013). The Las Peñas record represents the first documentation for this accidental boreal transient.

\section{Long-billed Dowitcher Limnodromus scolopaceus}

Record no. 2015-019: Province of Sucumbíos, Río Napo near Añangu, 26 February 2015, P. Greenfield, D. Zorrilla and J. Guzmán (photo). 

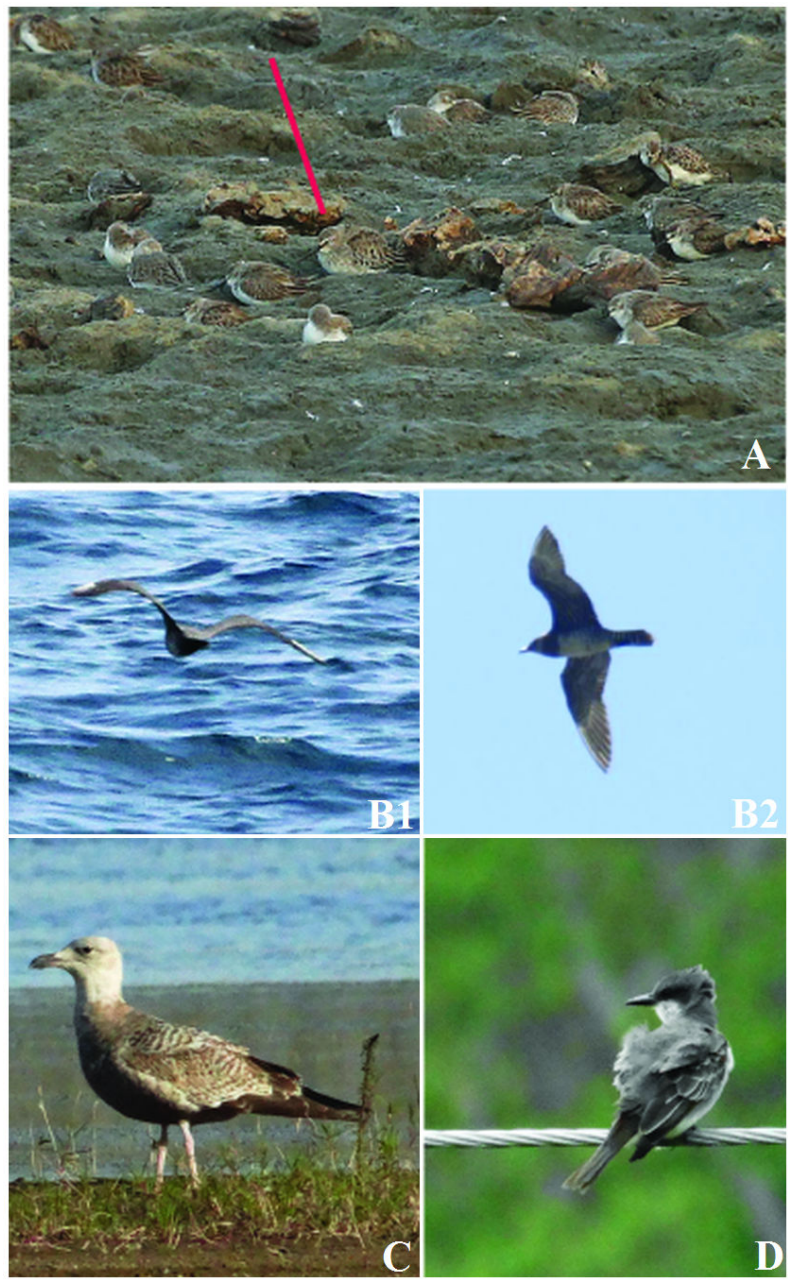

Figure 2: First documented records of species previously considered as hypothetical in Ecuador. a) Calidris alpina (R. Ahlman); b1) Stercorarius longicaudus (R. Ahlman); b2) Stercorarius longicaudus (C. Heese); c) Larus argentatus (J. Nilsson); d) Tyrannus dominicensis (J. Nilsson).

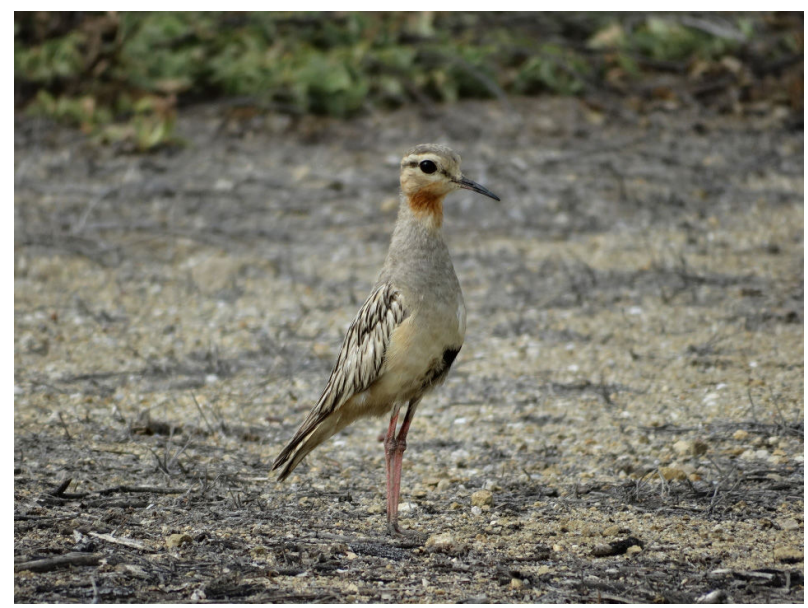

Figure 3: Tawny-throated Dotterel Oreopholus ruficollis, La Chocolatera, Ecuador (J. Nilsson).

A juvenile in first-winter plumage was observed in rather still water near the shoreline of a river island (Fig. 4e). Species identification was consulted with several experts on waders (R. S. Ridgely, L. Bevier, D. Paulson and N. van Duivendijk, in litt. 2015) and photos were uploaded at the electronic discussion forum of Dutch Birding (https://www. dutchbirding.nl/forum) resulting in an identification consensus as Limnodromus scolopaceus based on the following 

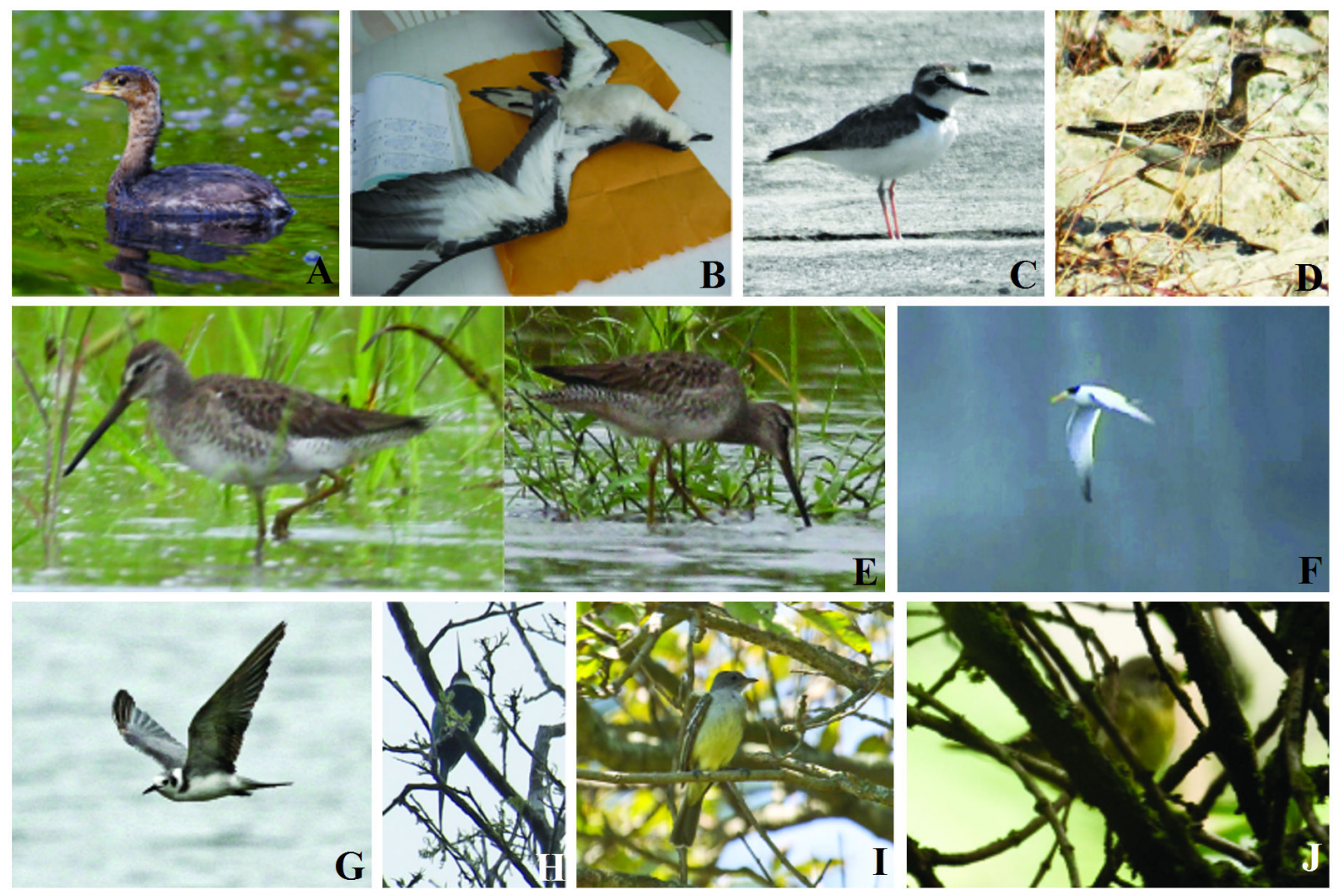

Figure 4: Major range extensions and extralimital records of birds in Ecuador. a) Podilymbus podiceps (C. Talkington); b) Pterodroma phaeopygia (J. M. Loaiza); c) Charadrius collaris (J. Nilsson); d) Bartramia longicauda (J. Nilsson); e) Limnodromus scolopaceus (D. Zorrilla, J. Guzmán); f) Sternula superciliaris (J. Nilsson); g) Chlidonias niger (R. Ahlman); h) Galbula dea (D. M. Brinkhuizen); i) Elaenia spectabilis (D. M. Brinkhuizen); j) Geothlypis philadelphia (D. M. Brinkhuizen).

field marks: scapular feather edging, breast and flank pattern, tail pattern, primary projection, shape of loral stripe, and bill shape at tip. The species was only recently confirmed for Ecuador (Putnam et al., 2009; Freile et al., 2013). This record is the first for the entire Amazon basin (Van Gils et al., 2016).

\section{Red Phalarope Phalaropus fulicarius}

Record no. 2015-027: Province of Esmeraldas, north of Las Peñas, 2 December 2014, J. Nilsson.

An adult in non-breeding plumage was observed in a marsh along the coast. There are very few inland and coastal records in Ecuador from Santa Elena peninsula (Haase, 2011). The species is more often seen at sea during pelagic trips (Ridgely \& Greenfield, 2001), and primarily from Santa Elena peninsula and Isla de la Plata areas.

\section{Chilean Skua Stercorarius chilensis}

Record no. 2014-064: Province of Santa Elena, La Chocolatera, 7 August 2014, R. Ahlman.

A bird was observed migrating south in powerful, low flight, amidst a continuous passage of Sooty Shearwaters Ardenna grisea that were also migrating south. Identification was based on size, reddish tone to underparts, dark cap, and extent of white at the base of primaries (Olsen \& Larssen, 1997). There is a single previous published record of a Stercorarius skua in Salinas, Ecuador, but it was not safely identified to species (Ridgely \& Greenfield, 2001). This record was made by B. Haase at Salinas (Ridgely \& Greenfield 2001), who considered it as unconfirmed (B. Haase, in litt. 2011). T. Seimola also reported a flyby S. chilensis from the province of Santa Elena, but further details have not yet been submitted. Further information is needed to confirm the status of S. chilensis in Ecuador, as well as that of other large skuas (South Polar S. maccormicki and Brown S. antarticus). 

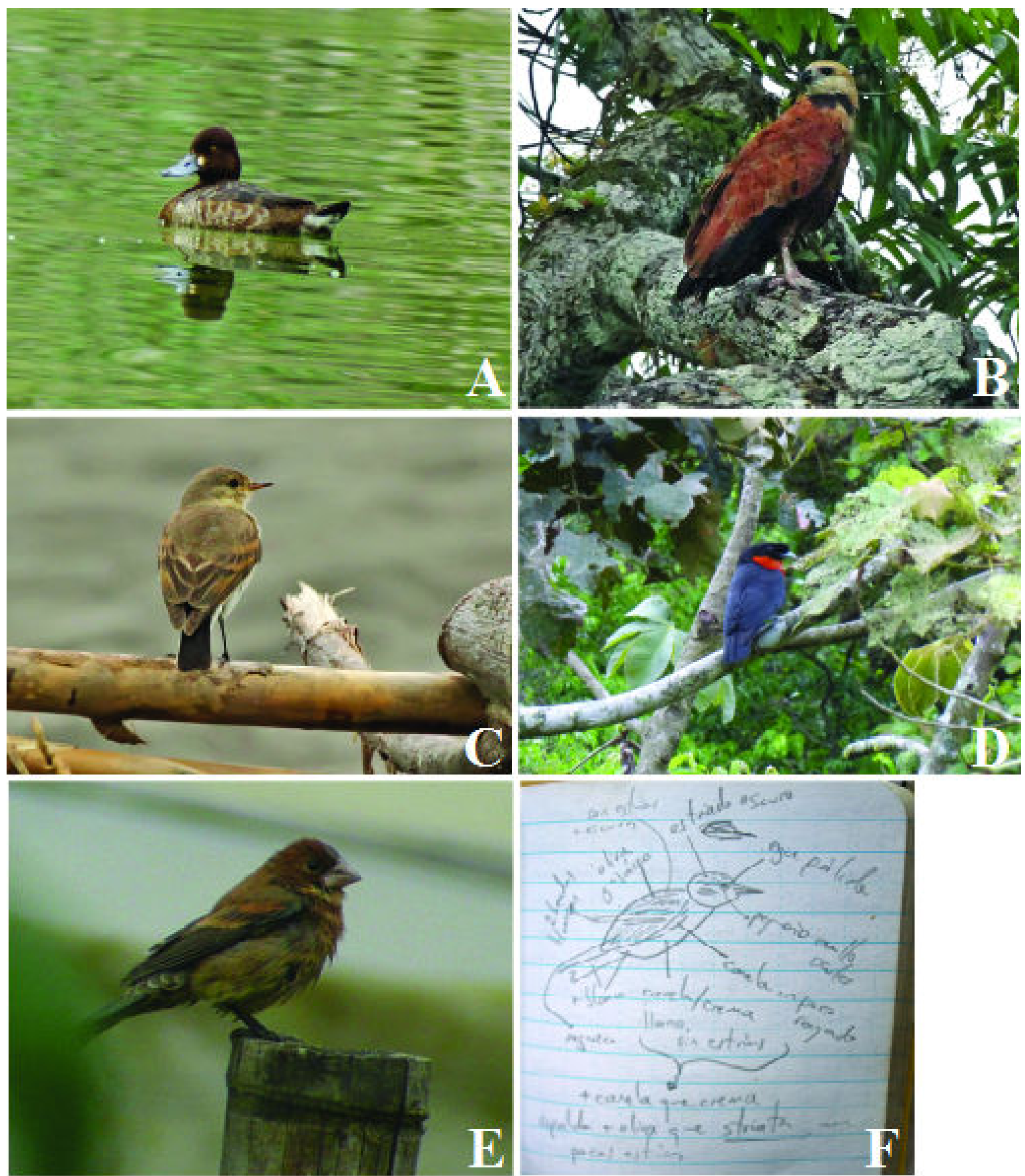

Figure 5: Rare birds recorded in Ecuador. a) Aythya affinis (J. Bedoya); b) Busarellus nigricollis (R. Ahlman); c) Muscisaxicola fluviatilis (R. Ahlman); d) Pyroderus scutatus (V. Obando); e) Passerina caerulea (R. Vickers); f) Setophaga castanea (J. Freile).

\section{Long-tailed Jaeger Stercorarius longicaudus}

Record no. 2015-025: Province of Santa Elena, pelagic off Salinas, 20 September 2014, R. Ahlman (photo).

Record no. 2014-064: Provinces of Orellana/Sucumbíos, Río Napo, 18 September 2008, C. Hesse (photo).

A single adult was observed and photographed flying 5-8 m above the ocean, $10-15 \mathrm{~km}$ off the coast of Salinas, in rather fast and steady flight in a southward direction (Fig. 2b1). Another single immature was observed and photographed flying along the Napo River (Fig. 2b2). As far as we are aware, this unexpected inland record represents the first for the Amazon basin (Furness et al., 2016). These records provide the first documentation of the species 
in Ecuador, which was previously known only from a few observations from the Salinas area (Ridgely \& Greenfield, 2001). Haase (2011) reported a washed-out specimen photographed at Mar Bravo, but not collected; photos of this specimen remain unpublished.

\section{Herring Gull Larus argentatus}

Record no. 2015-024: Province of Pichincha, Aeropuerto de Quito, Tababela, and Reservorio de Cumbayá, 20 December 2014-26 April 2015, J. Nilsson (photo).

A bird in first-winter plumage was first found at the reservoir west of Quito's Airport in Tababela (Fig. 2c). Given the complicated identification of large gulls and their age, a thorough study of the bird's plumage was made. Species identification was based on: 1) pale gray inner primaries forming a contrasting pale window against darker secondaries and outer primaries [separating it from all subspecies of Lesser Black-backed Gull L. fuscus, California Gull L. californicus, which has darker primaries with only a faint window, and Slaty-backed Gull L. schistisagus, which has pale webs on the outer primaries; see Howell \& Dunn, 2007]; 2) dark markings on the tips of the inner webs of primaries $1-3 ; 3)$ smoky, uniform underparts, neck and mantle especially on mid-belly, without any obvious streaking, lining or spots; 4) undertail coverts broadly barred blackish, with thinner and paler off-white bars (separating it from other taxa in the Herring Gull complex, which normally has darker bars thinner than pale ones; this also rules out Slatybacked Gull and Western Gull L. occidentalis); 5) heavily barred uppertail coverts with fairly broad dark bars, with the darker bars being broader than the paler ones; 6) mainly dark blackish tail with some paler mottling on the outer web of the outermost rectrices; 7) black bill with pale base to the lower mandible; 8) mainly dark tertials with paler fringes/notches on the tips only; 9) dark smudgy brown on the mantle and lower neck, contrasting with paler head; 10) irregular pattern on the scapulars; 11) a hint of a darker bar on the greater coverts on one wing; 12) irregular pattern on the wing coverts (see Howell \& Dunn, 2007). There is a single previous record of an adult-plumaged individual seen at the Napo River upstream of La Selva lodge on 13 February 1991 (Ridgely \& Greenfield, 2001). A photograph of apparently the same individual, taken by J. M. Carrión at Cumbayá reservoir, was published by Cisneros-Heredia et al. (2015). These observations in the Quito area represent the first documented records for Ecuador. The photographed individual belonged to the North American Larus argentatus smithsonianus subspecies, which is often considered as a separate species from the European Herring Gull L. argentatus (Crochet et al., 2002).

\section{Yellow-billed Tern Sternula superciliaris}

Record no. 2015-012: Province of Pichincha, Aeropuerto de Quito, Tababela, 10 November 2014, J. Nilsson (photo).

An adult in non-breeding plumage was observed at the artificial reservoir west of the airport (Fig. 4f). This represents the first highland record for Ecuador (Ridgely \& Greenfield, 2001). The species is a resident breeder of the Amazon lowlands, occurring up to $400 \mathrm{~m}$ along the Napo River (Ridgely \& Greenfield, 2001). We are not aware of other records elsewhere in the Andes.

\section{Black Tern Chlidonias niger}

Record no. 2014-056: Province of Sucumbíos, Laguna de Limoncocha, 28 May 2014, R. Ahlman (photo).

A sub-adult bird was seen and photographed at Laguna de Limoncocha (Fig. 4g). The species is considered as an uncommon to erratic transient in the country (Ridgely \& Greenfield, 2001). This observation is likely the fourth record from Amazonian Ecuador, and the second from this locality (Tallman \& Tallman, 1977; Freile et al., 2013).

\section{Common Nighthawk Chordeiles minor}

Record no. 2015-018: Province of Pichincha, Reservorio de Cumbayá, 28 October 2014, J. Nilsson.

Ten birds were observed flying back and forth high over a semi-urban creek with a mixture of vegetation and buildings. There are a few records of the species in Andean and western Ecuador, but it likely is semi-regular in the inter-Andean valleys around Quito (Ridgely \& Greenfield, 2001). There is little information on numbers passing through Ecuador, but elsewhere it is known to migrate in flocks of up to 20-40 individuals (Cleere \& Nurney, 1998). This record of 10 birds is likely the highest published count in Ecuador, with an additional flock of 13 individuals reported (Stotz, 2008) at Río Verde, Sucumbíos Province, in October 2008. 


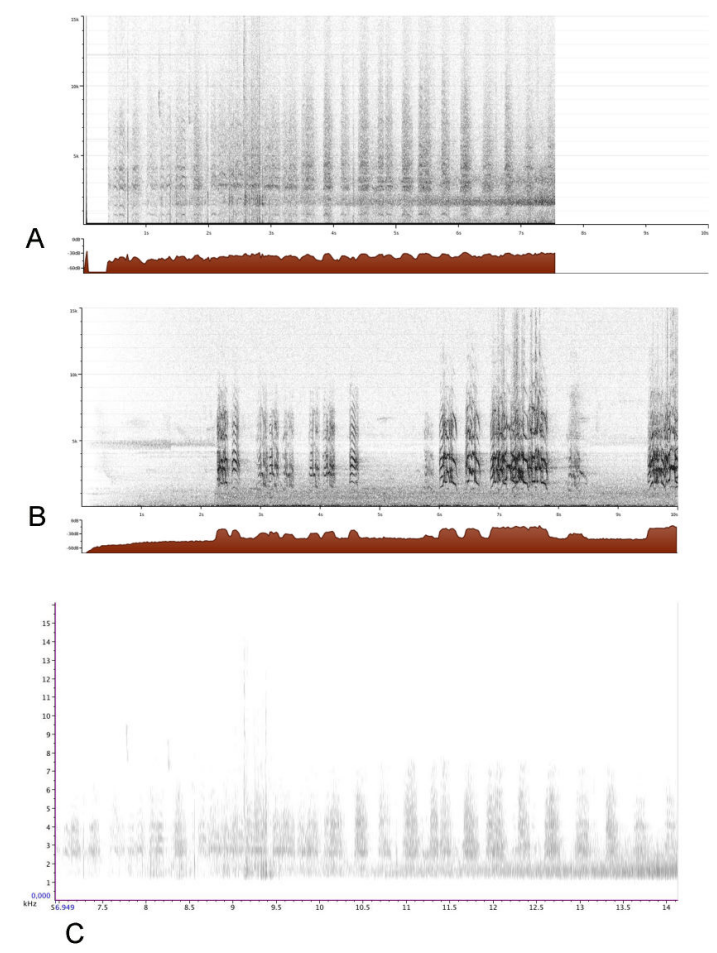

Figure 6: Sonograms of the flight calls of: a) and c) flock of Scarlet-fronted Parakeet Psittacara wagleri (Lysinger, 2015), audio-recorded by M. Lysinger at Catamayo, Loja; b) flock of Red-masked Parakeet Psittacara erythrogenys (Krabbe, 1991), audio-recorded by N. Krabbe at Buenaventura, El Oro. Sonograms a) and b) generated by xeno-canto; sonogram c) generated with Raven Lite.

\section{Short-tailed Nighthawk Lurocalis semitorquatus}

Record no. 2015-028: Province of Pastaza, 7 km N of Canelos, 17 September 1996, N. Krabbe (audio recording).

A single bird was briefly observed and audio-recorded flying over a cultivated plot in a forested area. A later analysis of the audio recording (Krabbe, 1996b), revealed that it is attributable to the nominate subspecies. The voice matches other recordings of Lurocalis semitorquatus semitorquatus, being notably different from L. s. nattereri (Fig. 7), the only subspecies previously recorded in E Ecuador (Ridgely \& Greenfield, 2001). Calls of L. s. nattereri are much longer $(0.2-0.3 \mathrm{~s})$ than that of L. s. semitorquatus (about 0.03-0.04 s) (Fig. 7). Voices of the nominate subspecies are very similar to those of western subspecies L. s. stonei and L. s. noctivagus (Moore et al., 2013; Fig. 7), but their occurrence in the Amazonian lowlands seems less likely. In the light of the Peruvian records (Schulenberg et al., 2007) of L. s. semitorquatus, we believe that this subspecies, and not trans-Andean L. s. stonei or L. s. noctivagus, is expected to occur in SE Ecuador. Lurocalis s. noctivagus has been synonymised with L. s. stonei by Cleere (2016). Notably, L. s. nattereri has been recorded at Kapawi (Krabbe, 1996a; 1996c), c. 150 km southeast of Canelos.

\section{Paradise Jacamar Galbula dea}

Record no. 2014-061: Province of Sucumbíos, Tipischa, 15 June 2014, D. Brinkhuizen, R. Ahlman and J. Nilsson (photo).

Up to three birds were observed and audio-recorded at primary forest edge along a road (Fig. 4h; Ahlman, 2014; Brinkhuizen, 2014). There are a few, scattered records of this species across the Ecuadorian Amazon, most of them concentrated in the Pastaza River basin, with additional records from the Lagartococha River in easternmost Sucumbíos Province (Ridgely \& Greenfield, 2001). Its habitat preferences in Ecuador are not well known. 


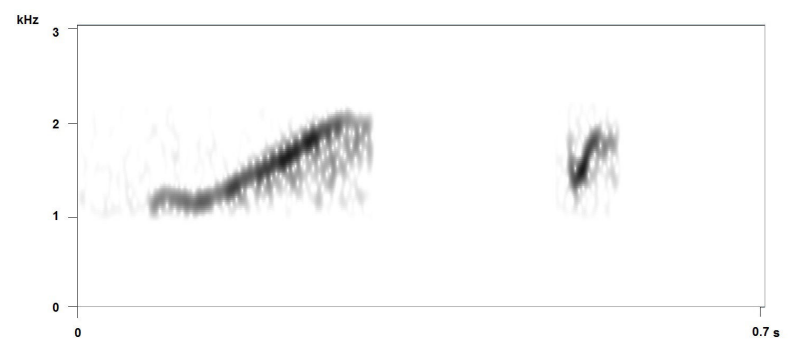

Figure 7: Sonogram of the calls of Short-tailed Nighthawk Lurocalis semitorquatus; left L. s. nattereri; right L. s. semitorquatus (new taxon to Ecuador); audio-recordings and sonogram by N. Krabbe.

\section{Scarlet-fronted Parakeet Psittacara wagleri}

Record no. 2015-008: Province of Loja, 3-4 km S of Catamayo airport, 15 March 2015, M. Lysinger (audio-recording; Fig. 6).

A flock of up to 18 individuals was recorded in Acacia scrubland near the entrance road to El Tambo (Lysinger, 2015). According to local residents, the species regularly congregates at this site after sunrise and during the day. There are only a few confirmed records of $P$. wagleri in southern Ecuador, including observations in the Catamayo valley (Ridgely \& Greenfield, 2001). Its status and distribution in Ecuador is poorly known, and the species is likely declining following extensive habitat disturbance and loss (Ribadeneira, 2002).

\section{Slaty-winged Foliage-gleaner Philydor fuscipenne}

Record no. 2014-044: Province of Los Ríos, Samana, 9-11 February 2011, J. Freile, F. Chiriboga and L. Rösiö.

Up to four pairs were observed and heard daily in secondary forest and forest borders, mainly attending mixed species flocks. The birds foraged actively on epiphytes along large branches, near tree trunks, and less often in dense foliage of terminal twigs. They often hung upside down or vigorously searched inside moss and epiphyte clumps. The species has become increasingly rare in Ecuador, where it has a small, fragmented and largely unprotected range (Ridgely \& Greenfield, 2001; Freile, 2002). There are a few recent records, mostly from El Oro province. The nearest record comes from Puente de Chimbo, Chimborazo province, $63 \mathrm{~km} \mathrm{~S}$ from Samana (Chapman, 1926; Ridgely \& Greenfield, 2001). The isolated Ecuadorian population might represent an undescribed, endemic taxon (Ridgely \& Greenfield, 2001; Remsen, 2003).

\section{Large Elaenia Elaenia spectabilis}

Record no. 2014-060: Province of Pichincha, Jardín Botánico de Quito, 25 September 2014, D. Brinkhuizen (photo).

A single individual was repeatedly observed from 25 September through 18 October 2014. It was active but elusive in treetops or inside shrubbery, and feeding on berries (Fig. 4i). This austral migrant has been recorded from a few localities in the eastern lowlands up to 600 m elevation (Ridgely \& Greenfield, 2001). As far as we are aware, the Quito record represents the first for the high Andes (Hosner, 2016).

\section{*Slaty Elaenia Elaenia strepera}

Record no. 2015-011: Province of Orellana, Tiputini Biodiversity Station, 19 March 2014, J. G. Blake and B. A. Loiselle (photo).

A single bird was mist-netted and photographed in slightly hilly terra firme forest understory with a relatively open canopy at Tiputini Biodiversity Station (Fig. 1c). Owing to its two prominent ochraceous wing bars, it was identified as an immature bird (Schulenberg et al., 2007). This is the first record of the species in Ecuador, though not entirely unexpected (Ridgely \& Greenfield, 2001). The species is known to breed in S Bolivia to NW Argentina and to winter in N Venezuela, with transient records in Amazonian Bolivia, Peru, and Colombia (Marantz \& Remsen, 1991). Our record involves a northbound transient, given that the species likely migrates northwards through western Amazonia 
from mid March to late April (Marantz \& Remsen, 1991).

\section{Little Ground-Tyrant Muscisaxicola fluviatilis}

Record no. 2014-052: Provinces of Orellana/Sucumbíos, river island on Río Napo, 12 July 2014, R. Ahlman, D. Gualinga, F. Broulik and S. Magee (photo).

A single bird was observed and photographed at close range on a river island sandbar, littered with driftwood logs and debris (Fig. 5c). This sighting is the first record with photographic evidence for the country, as previous records involved birds observed along the same general area of the Río Napo (Ridgely \& Greenfield, 2001). The species is presumably a non-breeding visitor to Ecuador, with only three additional records (Ridgely \& Greenfield, 2001).

\section{Grey Kingbird Tyrannus dominicensis}

Record no. 2015-005: Province of Esmeraldas, Atacames bypass, 2 December 2014, J. Nilsson (photo).

Two birds were observed on 2 December 2014 and a single on 27 January 2015 at two sites along the Atacames bypass (Fig. 2d). The first two individuals were seen perching on wires along a road bordered by scattered trees and bushes. The second sighting, most likely one of the two individuals seen on 2 December 2014, was in fairly dense vegetation at low to mid heights, on a few occasions perching atop trees. This represents the first documented record of $T$. dominicensis for Ecuador, the only previous one being an observation from Puerto Pitahaya, El Oro province (Ridgely \& Greenfield, 2001).

\section{Red-ruffed Fruitcrow Pyroderus scutatus}

Record no. 2015-001: Province of Carchi, El Corazón de Nuevo Mundo, 17 November 2014, V. E. Obando-Clavijo (photo).

Three birds were observed in a Cecropia-dominated forest patch surrounded by pastureland (Fig. 5d). The birds were apparently consorting with a group of six Andean Cock-of-the-rocks Rupicola peruvianus. They were also vocalizing frequently, which suggests the presence of a lek. The western Andean slopes of Carchi Province are likely a stronghold for the species in Ecuador, given that most recent records come from the same general area, 16-20 km N of El Corazón de Nuevo Mundo (Freile et al., 2013).

\section{Cliff Swallow Petrochelidon pyrrhonota}

Record no. 2015-010: Province of Pichincha, Reservorio de Cumbayá, 7 October 2014, J. Nilsson (photo).

One was observed perching on wires and flying low above water (Fig. 8). Its dark chestnut forehead indicates the subspecies Petrochelidon pyrrhonota melanogaster (Clements et al., 2015), previously known from a single record in Ecuador (Freile et al., 2013). Other subspecies are excluded by coloration of forehead and undertail coverts (Turner, 2004).

\section{Blue Grosbeak Passerina caerulea}

Record no. 2014-043: Province of Napo, camino de Borja, 15 March 2014, R. Vickers (photo).

A female was first reported at eBird (Vickers, 2014) and later submitted to CERO without details of habitat, behavior, weather conditions during observation, and time of the day (Fig. 5e). This is the third published record of the species in Ecuador and the first for the Andean slopes (Ridgely \& Greenfield, 2001; Brinkhuizen et al., 2011).

\section{Golden-winged Warbler Vermivora chrysoptera}

Record no. 2015-020: Province of Pichincha, 15 km between Pachijal-Guayabillas road, 25 March 2015, R. D. M. Edgar and J. C. Calvachi.

A single male was observed moving rapidly and exploring undersides of leaves close to a Canada Warbler Cardellina canadensis at the forest edge. It is considered a rare boreal migrant to the country (Ridgely \& Greenfield, 2001), with 


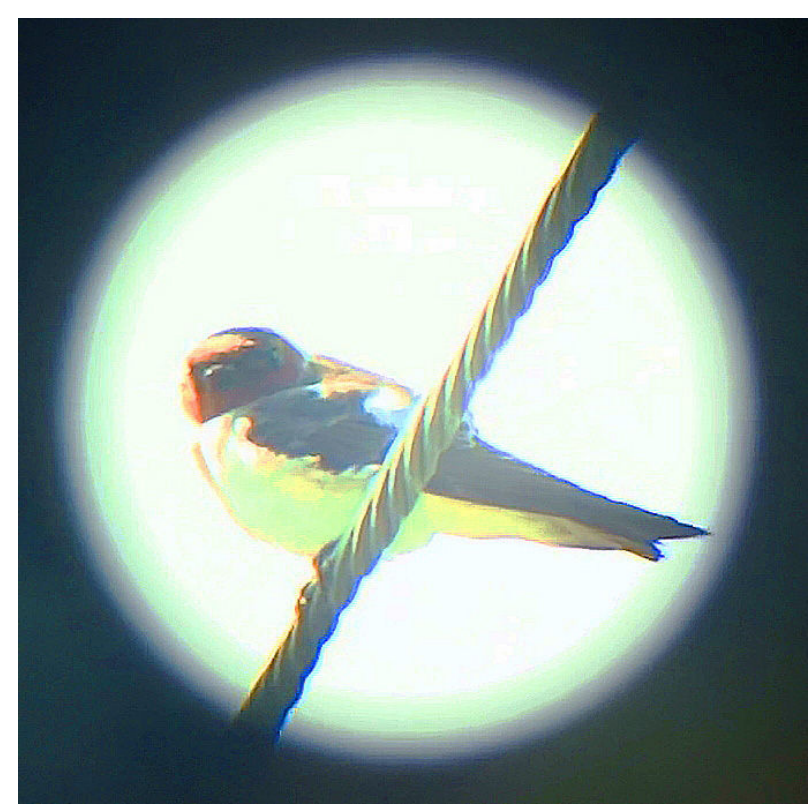

Figure 8: Second record of Petrochelidon pyrrhonota melanogaster in Ecuador (J. Nilsson).

few records, the most recent being a female at Yanayacu, Napo Province, in 2012 (Freile et al., 2013); the closest locality is Mindo, were first seen in February 1981 (Ridgely \& Greenfield, 2001). Due to the limited number of records and the species' recent population decline (Buehler et al., 2007), CERO encourages the submissions of all records in the country.

\section{Mourning Warbler Geothlypis philadelphia}

Record no. 2014-059: Province of Pichincha, Jardín Botánico de Quito, 28 October 2014, D. Brinkhuizen (photo).

One immature was seen on 28 October and one adult on 14 November 2014, mostly skulking low in dense bushes (Fig. $4 \mathrm{j})$. This is the first record of the species in the Inter-Andean valleys of Ecuador, and the highest elevation recorded for the species (Curson, 2016). Otherwise, it is known from a few localities along the Andean subtropics, foothills, and adjacent lowlands, in Pichincha, Napo, Orellana, and Tungurahua provinces (Ridgely \& Greenfield, 2001).

\section{Bay-breasted Warbler Setophaga castanea}

Record no. 2014-045: Province of Orellana, Río Bigal Biological Reserve, 4 January 2014, J. Freile (field sketch).

A single bird was observed attending a mixed-species flock in the mid-story of secondary forest edge (Fig. 5f). Blackpoll Warbler Setophaga striata was the only other boreal migrant warbler detected in the same flock. Recent records of $S$. castanea from several new localities in northern Ecuador, including Cascada de San Rafael and Bermejo, in Napo and Sucumbíos provinces respectively, suggest that it may be a regular, but rare visitor here (Ridgely \& Greenfield, 2001; Nilsson et al., 2014). Identification in non-breeding plumage from the very similar $S$. striata might be difficult, so CERO encourages documentation of sightings.

\section{Invalidated records}

In tandem with a previous CERO report (Nilsson et al., 2014), we revised the status of an additional species whose occurrence in Ecuador was considered unlikely (Ridgely \& Greenfield, 2001).

\section{Plain-breasted Piculet Picumnus castelnau}

Record no. 2015-x01: two specimens reportedly collected at Sarayacu (1862) and Río Napo (1890) localities.

Two XIX century specimens with imprecise collection data were the only evidence available for Ecuador (Río Napo 
and Sarayacu). Schulenberg (2013) recently showed that the species was collected in a Sarayacu locality along the Ucayali River, Peru (Stephens \& Traylor, 1983), because its collector (Francis de LaPorte de Castelnau) actually never visited Ecuador. Further, as discussed by Ridgely \& Greenfield (2006), the Río Napo locality might be located in the lower section of the river, which currently corresponds to Peru but was within Ecuadorian territory until the 1940s. Chapman (1926) correctly assigned the species to Ecuador because at that time, Ecuador extended east all the way to the mouth of the Napo River into the Marañón River. Later changes in Ecuador's official boundaries excluded the species from the country's territory. Given the absence of any modern records, we conclude that the species should be removed from the Ecuadorian bird fauna (see also Ridgely \& Greenfield, 2006).

Table 2: Summary of rejected records submitted to the Committee for Ecuadorian Records in Ornithology (CERO) between April 2014 and August 2015.

\begin{tabular}{|c|c|c|c|c|}
\hline Record number & Species & $\begin{array}{l}\text { Locality, } \\
\text { province }\end{array}$ & Date & Notes \\
\hline 2014-057 & $\begin{array}{c}\text { Flesh-footed } \\
\text { Shearwater Ardenna } \\
\text { carneipes }\end{array}$ & $\begin{array}{l}\text { La Chocolatera, } \\
\text { Santa Elena }\end{array}$ & 5 August 2014 & $\begin{array}{c}\text { Insufficient } \\
\text { information } \\
\text { to exclude } \\
\text { other shearwaters }\end{array}$ \\
\hline $2015-013$ & $\begin{array}{c}\text { Wilson's Storm-Petrel Oceanites } \\
\text { oceanicus }\end{array}$ & $\begin{array}{l}\text { La Chocolatera, } \\
\text { Santa Elena }\end{array}$ & 6 September 2014 & $\begin{array}{l}\text { Insufficient information } \\
\text { to exclude other } \\
\text { storm-petrels }\end{array}$ \\
\hline $2014-058$ & Brown Bobby Sula leucogaster & $\begin{array}{l}\text { San Sebastián, } \\
\text { Galápagos }\end{array}$ & No date & $\begin{array}{l}\text { Insufficient } \\
\text { information } \\
\text { to exclude } \\
\text { other bobbies }\end{array}$ \\
\hline $2014-047$ & $\begin{array}{l}\text { Mississippi Kite Ictinia } \\
\text { mississippiensis }\end{array}$ & $\begin{array}{l}\text { La Selva, } \\
\text { Sucumbíos }\end{array}$ & 19 February 2014 & $\begin{array}{c}\text { Misidentified } \\
\text { Plumbeous Kite } I . \\
\text { plumbea }\end{array}$ \\
\hline 2014-049 & $\begin{array}{c}\text { Long-tailed Jaeger Stercorarius } \\
\text { longicaudus }\end{array}$ & $\begin{array}{l}\text { Canal Bolívar, } \\
\text { Galápagos }\end{array}$ & 23 September 2014 & $\begin{array}{l}\text { Insufficient } \\
\text { information to } \\
\text { exclude other } \\
\text { jaegers }\end{array}$ \\
\hline $2015-025$ & $\begin{array}{l}\text { Long-tailed Jaeger Stercorarius } \\
\text { longicaudus }\end{array}$ & $\begin{array}{l}\text { La Chocolatera, } \\
\text { Santa Elena }\end{array}$ & 4 September 2014 & $\begin{array}{l}\text { Insufficient } \\
\text { information to } \\
\text { exclude other } \\
\text { jaegers }\end{array}$ \\
\hline 2014-046 & $\begin{array}{c}\text { Peruvian Pigeon Patagioenas } \\
\text { oenops }\end{array}$ & $\begin{array}{l}\text { Playas de Chito, } \\
\text { Zamora Chinchipe }\end{array}$ & 20 September 2007 & $\begin{array}{c}\text { Deficient } \\
\text { documentation }\end{array}$ \\
\hline 2014-051 & Southern Martin Progne elegans & $\begin{array}{l}\text { Limoncocha, } \\
\text { Sucumbíos }\end{array}$ & 28 May 2014 & $\begin{array}{l}\text { Insufficient } \\
\text { information to } \\
\text { exclude Purple } \\
\text { Martin P. subis }\end{array}$ \\
\hline $2015-022$ & $\begin{array}{c}\text { *Stripe-tailed } \\
\text { Yellow-Finch Sicalis citrina }\end{array}$ & $\begin{array}{l}\text { near Guadual, } \\
\text { Imbabura }\end{array}$ & 24 January 2015 & $\begin{array}{c}\text { Deficient } \\
\text { documentation }\end{array}$ \\
\hline
\end{tabular}

\section{Rejected records}

Nine records were rejected (Table 2) due to insufficient information for accurately assessing them. Those records include one species not previously found in Ecuador, one species not previously found in continental Ecuador, three species that lack voucher documentation in Ecuador, one rare austral pelagic, one rare austral migrant in continental Ecuador, and one rare wanderer to the Galapagos Islands. Lastly, the revision of one record of Green Heron Butorides virescens was postponed pending further revision of submitted material by experts on ardeids. 


\section{ACKNOWLEDGMENTS}

We thank all observers who submitted their records to CERO (see under species accounts). Special thanks to Roger Ahlman, former chair of CERO, for all his committed work and his numerous observations submitted to date. Thanks to external advisory on some species identification provided by Alvaro Jaramillo, Steve N. G. Howell, Daniel F. Lane, Ben Haase, Tuomas Seimola, Louis Bevier, Dennis Paulson and Nils van Duivendijk; also to Niels Krabbe and one anonymous referee for their comments, and to our institutions and tour operators for allowing us to take regular field trips.

\section{REFERENCES}

Ahlman, R. (2014). XC 182548 Paradise Jacamar, Galbula dea. Xeno-canto. URL: http://www.xeno-canto.org/182548

Ahlman, R. (2016). Green-winged Teal Anas crecca carolinensis, first record for Ecuador. Cotinga, $38,40$.

BirdLife International. (2016, April 28). Species factsheet: Numenius americanus. BirdLife International. URL: http://www. birdlife.org.

Brinkhuizen, D. M. (2014). XC 182345 Paradise Jacamar, Galbula dea. Xeno-canto. URL: http://www.xeno-canto.org/182345

Brinkhuizen, D. M., López, D., Ferrer, J., Rodríguez, G., Ardaiz, J. \& Seitz, L. (2011). First record of Blue Grosbeak

Passerina caerulea in western Ecuador. Cotinga, 33, 81 .

Buehler, D.A., Roth, A.M., Vallender, R., Will, T.C., Confer, J.L., Canterbury, R.A., Swarthout, S.B., Rosenberg, K.V. \& Bulluck, L.P. (2007). Status and conservation priorities of Golden-winged Warbler (Vermivora chrysoptera) in North America. Auk, 124(4), 1439-1445. DOI: http://dx.doi.org/10.1642/0004-8038(2007)124[1439:SACPOG]2.0.CO;2

Carboneras, C., Jutglar, F. \& Kirwan, G.M. (2016, October 31). Manx Shearwater (Puffinus puffinus). En J. del Hoyo, A. Elliott, J. Sargatal, D.A. Christie \& E. de Juana (Eds.), Handbook of the birds of the world alive. Barcelona, España: Lynx Edicions. URL: http://www.hbw.com/node/52573

Chapman, F.M. (1926). The distribution of bird-life in Ecuador. Bulletin of the American Museum of Natural History, 55, 1784.

Cisneros-Heredia, D.F., Amigo, X., Arias, D., Arteaga, J., Bedoya, J., Espinosa, S., Montenegro, E., Nazati, G. \& Carrión, J.M. (2015). Reporte del 1er Conteo Navideño de Aves de Quito, Ecuador. Avances en Ciencias e Ingenierías, 7(2), B37-B51. DOI: http://dx.doi.org/10.18272/aci.v7i2.256

Cleere, N. (2016, October 31). Short-tailed Nighthawk (Lurocalis semitorquatus). En J. del Hoyo, A. Elliott, J. Sargatal, D.A. Christie \& E. de Juana (Eds.), Handbook of the birds of the world alive. Barcelona, España: Lynx Edicions. URL: http://www.hbw. com/node/55160

Cleere, N. \& Nurney, D. (1998). Nightjars: a guide to the nightjars and related birds. Robertsbridge, UK: Pica Press.

Clements, J.F., Schulenberg, T.S., Iliff, M.J., Roberson, D., Fredericks, T.A., Sullivan, B.L. \& Wood, C.L. (2015, Marzo 20). The eBird/Clements checklist of birds of the world: v2015. URL: http://www.birds.cornell.edu/clementschecklist/download/IOC

Crochet, P.A., Lebreton, J.D. \& Bonhomme, F. (2002). Systematics of large white-headed gulls: patterns of mitochondrial DNA variation in western European taxa. Auk, 119(3), 603-620. DOI: http://dx.doi.org/10.1642/0004-8038(2002)119[0603: SOLWHG]2.0.CO;2

Curson, J. (2016, Mayo 03). Mourning Warbler (Oporornis philadelphia). En J. del Hoyo, A. Elliott, J. Sargatal, D.A. Christie \& E. de Juana (Eds.), Handbook of the birds of the world alive. Barcelona, España: Lynx Edicions. URL: http://www.hbw.com/node/ 61506

Fjeldså, J. \& Krabbe, N. (1990). Birds of the high Andes. Copenhagen, Denmark: Apollo Books.

Freile, J.F. (2002). Limpiafrondas Alipizarrosa Philydor fuscipennis. En T. Granizo, C. Pacheco, M.B. Ribadeneira, M. Guerrero \& L. Suárez (Eds.), Libro rojo de las aves del Ecuador (pp. 280-281). Quito, Ecuador: Simbioe, Conservación Internacional, EcoCiencia, Ministerio del Ambiente and UICN.

Freile, J.F., Brinkhuizen, D.M., Solano-Ugalde, A., Greenfield, P.J., Ahlman, R., Navarrete, L. \& Ridgely, R.S. (2013). Rare birds in Ecuador: first annual report of the Committee of Ecuadorian Records in Ornithology (CERO). Avances en Ciencias e 
Ingenierías, 5(2), B24-B41. http://www.usfq.edu.ec/Publicaciones/Avances/B24-5-2-2013

Freile, J.F., Brinkuizen, D.M., Greenfield, P.J., Lysinger, M., Navarrete, L., Nilsson, J., Ridgely, R.S., Solano-Ugalde, A., Ahlman, R. \& Boyla, K.A. (2016, March 10). Lista oficial de las aves del Ecuador. Comité Ecuatoriano de Registros Ornitológicos. URL: http://www.ceroecuador.wordpress.com

Furness, R.W., Kirwan, G.M. \& de Juana, E. (2016, March 28). Long-tailed Jaeger (Stercorarius longicaudus). En J. del Hoyo, A. Elliott, J. Sargatal, Christie, D.A. \& E. de Juana (Eds.), Handbook of the Birds of the World Alive. Barcelona, Spain: Lynx Edicions. URL: http://www.hbw.com/node/53960.

García-Godos, I. (2002) First record of the Cape Gannet Morus capensis for Peru and the Pacific Ocean. Marine Ornithology, 30(1), 50. http://www.marineornithology.org/PDF/30_1/30_1_16.pdf

Granizo, T. (2002). Chorlo Cabezón Cuellicanelo Oreopholus ruficollis. En T. Granizo, C. Pacheco, M.B. Ribadeneira, M. Guerrero \& L. Suárez (Eds.), Libro rojo de las aves del Ecuador (pp. 63). Quito, Ecuador: Simbioe, Conservación Internacional, EcoCiencia, Ministerio del Ambiente and UICN.

Haase, B. (2011). Aves marinas de Ecuador continental y acuáticas de las piscinas artificiales de Ecuasal. Guayaquil, Ecuador: Aves \& Conservación, BirdLife International and Ecuasal S. A.

Harrison, P. (1987). Seabirds of the world: a photographic guide. London, UK: Christopher Helm.

Hayman, P., Marchant, J. \& Prater, T. (1986). Shorebirds. An identification guide. Boston: Houghton Mifflin Company.

Hosner, P. (2016, March 10). Large Elaenia (Elaenia spectabilis). En J. del Hoyo, A. Elliott, J. Sargatal, D.A. Christie \& E. de Juana. (Eds.), Handbook of the Birds of the World Alive. Barcelona, Spain: Lynx Edicions. URL: http://www.hbw.com/node/ 57143.

Howell, S.N.G. (2012). Petrels, albatrosses, and storm-petrels of North America: a photographic guide. Princeton: Princeton University Press.

Howell, S.N.G. \& Dunn, J. (2007). A reference guide to gulls of the Americas. Boston: Houghton Mifflin Company.

Janni, O. \& Pulcher, C. (2007). Reidentification of Ecuadorian specimens of Pachyramphus rufus as P. castaneus. Bulletin of the British Ornithologists Club, 127(3), 246-247. http://www.biodiversitylibrary.org/item/127048\#page/80/mode/1up

Kirwan, G.M., Calderón, D., Minns, J. \& Roesler, I. (2012). Neotropical notebook. Cotinga, 34, $179-194$.

Krabbe, N. (1991). XC238921 Red-masked Parakeet, Psittacara erythrogenys. Xeno-canto. URL: http://www.xeno-canto.org/ 238921

Krabbe, N. (1996a). XC238440 Short-tailed Nighthawk, Lurocalis semitorquatus. Xeno-canto. URL: http://www.xeno-canto. $\operatorname{org} / 238440$

Krabbe, N. (1996b). XC 238442 Short-tailed Nighthawk, Lurocalis semitorquatus. Xeno-canto. URL: http://www.xeno-canto. org/238442

Krabbe, N. (1996c). XC 238443 Short-tailed Nighthawk, Lurocalis semitorquatus. Xeno-canto. URL: http://www.xeno-canto. org/238443

Lysinger, M. (2015). XC 314108 Scarlet-fronted Parakeet, Psittacara wagleri. Xeno-canto. URL: http://www.xeno-canto.org/ 314108

Olsen, K.M., \& Larsson, H. (1997). A guide to the skuas and jaegers of the world. New Haven: Yale University Press.

Onley, D., \& Scofield, P. (2007). Albatrosses, petrels and shearwaters of the world. London, UK: Helm Field Guides.

Madge, S., \& Burn, H. (1988). Waterfowl. An identification guide to the ducks, geese and swans of the world. Boston: Houghton Mifflin Company.

Marantz, C.A., \& Remsen, J.V. (1991). Seasonal distribution of the Slaty Elaenia, a little-known austral migrant of South America. Journal of Field Ornithology, 62(2), 162-172. http://www.jstor.org/stable/4513620

Moore, J.V., Krabbe, N. \& Jahn, O. (2013). Bird sounds of Ecuador, a comprehensive collection. San Jose, California: John 
V. Moore Nature Recordings.

Nilsson, J., Freile, J.F., Ahlman, R., Brinkhuizen, D.M., Greenfield, P.J., \& Solano-Ugalde, A. (2014). Rare birds in Ecuador: second annual report of the Committee for Ecuadorian Records in Ornithology (CERO). Avances en Ciencias e Ingenierías, 6(2), B38-B50. http://www.usfq.edu.ec/publicaciones/avances/archivo_de_contenidos/Documents/volumen_6_numero_2/012_6_ 2_2014.pdf

Pearson, D.L., Tallman, D. \& Tallman, E. (1972). Birds of Limoncocha. Quito, Ecuador: Instituto Lingüistico de Verano.

Putnam, C., Jones, A. \& Ridgely, R.S. (2009). Two Long-billed Dowitcher Limnodromus scolopaceus specimens from Ecuador. Cotinga, 31, 130-132.

Remsen, J.V. 2003. Family Furnariidae (ovenbirds). En J. del Hoyo, A. Elliott \& D. Christie (Eds.), Handbook of the birds of the world, volume 8: broadbills to tapaculos (pp. 162-357). Barcelona, Spain: Lynx Edicions.

Remsen, J.V., Areta, J.I., Cadena, C.D., Jaramillo, A., Nores, M., Pacheco, J.F., Pérez-Emán, J., Robbins, M.B., Stiles, F.G., Stotz, D.F. \& Zimmer, K.J. (2016, August 8). A classification of the bird species of South America. American Ornithologists' Union. URL: http://www.museum.lsu.edu/ Remsen/SACCBaseline.html

Restall, R., Rodner, C., \& Lentino, M. (2006). Birds of northern South America. An identification guide. London, UK: Helm Field Guides.

Ribadeneira, M.B. (2002). Perico Frentiescarlata Aratinga wagleri. En T. Granizo, C. Pacheco, M.B. Ribadeneira, M. Guerrero \& L. Suárez (Eds.), Libro rojo de las aves del Ecuador (pp. 85). Quito, Ecuador: Simbioe, Conservación Internacional, EcoCiencia, Ministerio del Ambiente and UICN.

Ridgely, R.S. \& Greenfield, P.J. (2001). The birds of Ecuador. Ithaca: Cornell University Press.

Ridgely, R.S. \& Greenfield, P.J. (2006). Aves del Ecuador. Quito, Ecuador: Academia de Ciencias de Philadelphia and Fundación Jocotoco.

Salvadori, T. \& Festa, E. (1900). Viaggo del Dr. Enrico Festa nell'Ecuador. XII: Uccelli. Parte terza-Trochili-Tinami. Bolletino dei Musei di Zoologia ed Anatomia Comparata della Reale Universita di Torino, 15(368), 1-54. http://www.biodiversitylibrary.org/ item/43398\#page/13/mode/1up

Santander, T., Terán, K., Mueces, T., Lara, A., Llumiquinga, C. \& Guevara, E.A. (2011). Registros inusuales de aves costeras en lagunas altoandinas de Ecuador. Cotinga, 33, 105-107.

Schulenberg, T.S. (2013). The type locality of Plain-breasted Piculet Picumnus castelnau is valid. Bulletin of the British Ornithologists Club, 133(1), 77-78.

Schulenberg, T.S., Stotz, D.F., Lane, D.F., O'Neill, J.P. \& Parker, T.A. (2007). Birds of Peru. London, UK: Helm Field Guides.

Sibley, D.A. (2003). The Sibley field guide to the birds of western North America. New York: Knopf Doubleday Publishing.

Stephens, L. \& Traylor, M.A. (1983). Ornithological gazetteer of Peru. Cambridge, Massachusetts: Museum of Comparative Zoology. http://www.biodiversitylibrary.org/page/14527749\#page/3/mode/1up

Stotz, D. F. (2008, October 22). eBird checklist: http://ebird.org/ebird/view/checklist/S12491103. eBird: An online database of bird distribution and abundance. Ithaca, New York. URL: http://www.ebird.org

Tallman, D.A. \& Tallman, E.J. (1977). Adiciones y revisiones a la lista de avifauna de Limoncocha, provincia del Napo, Ecuador. Revista de la Universidad Católica, 5(16), 217-224. http://www.puce.edu.ec/publicaciones/Centro_de_Publicaciones/Revistas/ Publicaciones/Revista\%2016.pdf

Turner, A. (2004). Family Hirundinidae (swallows and martins). En J. del Hoyo, A. Elliot \& D. Christie (Eds.), Handbook of the birds of the world, volume 9: cotingas to pipits and wagtails (pp. 602-685). Barcelona, Spain: Lynx Edicions.

Van Gils, J., Wiersma, P. \& Kirwan, G.M. (2016, March 9). Long-billed Dowitcher (Limnodromus scolopaceus). En J. del Hoyo, A. Elliott, J. Sargatal, D.A. Christie \& E. de Juana (Eds.), Handbook of the Birds of the World Alive. Barcelona, Spain: Lynx Edicions. URL: http://www.hbw.com/node/53886.

Vickers, R. (2014, Marzo 15). eBird checklist: http://ebird.org/ebird/view/checklist/S17564247. eBird: An online database of bird distribution and abundance. Ithaca, New York. URL: http://www.ebird.org 
Wiedenfeld, D.A. (2006). Aves, the Galapagos Islands, Ecuador. Check List, 2(2), 1-27. DOI: http://dx.doi.org/10.15560/2.2. 1 